\title{
Awareness Regarding Domestic Violence among Married Women in Nawalparasi, Nepal
}

\author{
Adhikari, I. (Poudel) ${ }^{1 *}$, Rai, $\mathrm{S}^{2}$, Budhathoki, $\mathrm{B}^{3} \&$ Gurau, $\mathrm{S}^{4}$ \\ ${ }^{I}$ Indira Adhikari (Poudel), Lecturer, Department of Nursing, Manmohan Memorial Institute of Health Sciences, Nepal. \\ ${ }^{2}$ Sabita Rai, Lecturer, Department of Nursing, Manmohan Memorial Institute of Health Sciences, Nepal. \\ ${ }^{3}$ Bamita Buthathoki, Associate Professor, Department of Nursing, Manmohan Memorial Institute of Health Sciences, Nepal. \\ ${ }^{4}$ Sadhana Gurau, Kaligandaki Samudayak Hospital, Kawasoti, Nawalparasi, Nepal. \\ Corresponding Author Email: Indira.adhikarip@ gmail.com ${ }^{1 *}$
}

DOI: http://doi.org/10.38177/AJBSR.2022.4105

Copyright: () 2022 Adhikari, I. (Poudel) et al. This is an open access article distributed under the terms of the Creative Commons Attribution License, which permits unrestricted use, distribution, and reproduction in any medium, provided the original author and source are credited.

\section{ABSTRACT}

Background: Violence is among the leading cause of death worldwide widely for people aged 15-49 years. Domestic violence is a common globa problem, which is usually hidden from the public view that affects every individual. World widely, $40-70 \%$ of females are murdered by their intimate partner. Methods: A descriptive cross-sectional study design was used and eighty married women were selected using probability systematic sampling technique from Kawasoti-13, Nawalparasi. Data was collected by using a structured interview schedule to find out the awareness regarding domestic violence. Data entry was done by IBM SPSS version 20. Results: The overall finding of the study revealed that the mean age of the respondent was $37.64 \pm 8.973$ years, $97.5 \%$ of respondents followed Hinduism, $76.3 \%$ were literate. Among literate $31.14 \%$ had completed basic education, $58.8 \%$ respondents were involved in agriculture and $60 \%$ respondents belong to nuclear families. Only $31.3 \%$ participated in the awareness program. About $47.5 \%$ had previously experienced domestic violence. Women's knowledge was higher on meaning higher knowledge on causes, types, and management of domestic violence whereas lower knowledge on laws of domestic violence. More than half $57.5 \%$ had adequate awareness regarding domestic violence. Conclusion: Based on the finding it can be concluded that nearly half of the married women had inadequate awareness regarding domestic violence. Therefore domestic violence awareness programs should be conducted at the community level for women to upgrade the level of awareness regarding domestic violence.

Keywords: Awareness, Domestic violence, Married women.

\section{Introduction}

Domestic violence mentions any violence, abusive behaviour, whether physical, sexual, psychological, emotional, verbal, or financial, in which one person controls and dominates another within an intimate relationship. Domestic violence has not only a devasting societal problem but also a severe medical and mental health problem worldwide [1]. The term "violence against women" encompasses many forms of violence, including violence by an intimate partner (intimate partner violence) and rape/sexual assault, and other forms of sexual violence perpetrated by someone other than a partner (non-partner sexual violence), likewise female genital mutilation, honour killings and the trafficking of women. The data shows that lifetime physical and sexual intimate partner violence among ever partnered women in Africa is $36.6 \%$, America is 29.8, Eastern Mediterranean is 37.0\%, Europe is $25.4 \%$, South Asia is 37.7\%, and Western Pacific 24.6\% [2]. In Mumbai at urban health centre among 105 women most common violence faced by women was verbal violence $71.42 \%$, physical violence among $48.57 \%$.

The perceived risk factors for violence were addiction (27.61\%), poverty (29.52\%), son preference (18.09\%), childlessness (1.9\%), dowry (3.8\%), husband's extramarital relationship (12.38\%), unemployment of husband (13.33\%), chronic illness of husband (3.8\%) and other (23.8\%) [3]. Among women of reproductive age in the village development committee in two districts, Sindhuli and Mahottari of Nepal, out of 355 women the prevalence of physical violence was $29.6 \%$, sexual violence was $6.8 \%$ and psychological violence was $31 \%$. Furthermore, 12.4 $\%$ of women were experiencing all forms of violence [4]. Around 70\% of Muslim women in India are victims of domestic violence, $60 \%$ of children face their mother's enmity. The main causes: demanding dowry, torture by 
husband and in-laws, arguing with the partner, refusing to have sex with the partner, neglecting children, going out of home without telling, indulging in extramarital affairs, not looking after in-laws, not cooking properly. Women who are mainly suffering from physical, psychological, and emotional conditions [5]. The prevalence of domestic violence was high among less-educated women than in highly educated women i.e. 8 out of 50 in college teachers and 50 out of 50 in sweepers respectively [6].

In Nepal, 2348 cases of violence against women and 700 cases of violence against girls were recorded this year. Among 2348 victims, 1569 are victims of domestic violence. A statistical representation of women victimization as per region showed, 303 cases of domestic violence in the Eastern Development Region, 651 cases in Central Developmental Region, 206 cases in the Western Developmental Region, 253 cases in Mid-Western Developmental Region, and 156 cases in Far Western Developmental Region \{Informal Sector Service Centre [7]. Nepal ranks 112 of 136 countries in gender equality. About $22 \%$ of women aged 15-49 years have experienced physical violence at least once since age 15 . Nearly 2 in 3 women have never told anyone about the violence they have experienced [8].

In 20 victims in Guriya municipality-8, Bardiya district of Nepal, the study shows that the root causes of the victim the violence against women was the low status of women in the community and economically dependent on the male. Other factors: unemployment, extramarital relation of husband, suspicious attitude, gambling, dowry and widowhood are causes of violence [9]. One study shows that 107 women were murdered by their husbands.

Out of those only 74 cases are filed. The paternal family members murdered 30 women, and their family members murdered 26 women. Among them, only 33 cases were filed [10]. The prevalence of domestic violence experienced by women was $28.9 \%$. All types of violence are more common in rural areas than the urban area. Mostly, spousal, emotional, and physical violence was the common type of violence [11]. The study conducted in India and the result shows that the domestic violence among women and its association socio-economic factors like marital age, education level and decision making power [12]. A study conducted on "Effects of Societal/Domestic Violence on Health of Women." which reveals that almost 1-20 percent of women has been victims of Domestic Violence even during their pregnancy. The major causes for domestic violence were marriages at early age, alcoholism, unemployment, and poverty [13].

Most of the areas of Bangladesh have domestic violence and internalized social norms and practices. Even domestic violence issues occurred victims are sent back to their abusive husband's homes. The victims are again faced with the same domestic violence problem likes the previous [14].

\section{Material and methods}

\subsection{Study Period}

The present study was done in the 2018 year (16 June-15 July) one month period. Study design, participants, and data collection a descriptive cross-sectional research design was used. The population of the study was married women who are involved in different women's groups (mothers group) of Kawasoti-13, Nawalparasi. There were a total of 7 women's groups and among the total population were 203. 


\subsection{Sampling Technique}

The sampling technique was the Probability systematic sampling technique. The required sample size (n) was 80 . The total population (N) is 203 . So, the sampling interval (K) was $203 / 80=2.5 \sim 2$. The first respondent was between 1 and 10 which was selected by simple random sampling technique. The second respondent was selected by adding the value of $\mathrm{K}$ to the first number and so on until the desired sample was obtained.

\subsection{Instrumentation}

The instrument for data collection was a structured interview schedule through the face-to-face interview method which was developed by the researcher herself reviewing the related literature and consulting with subject experts.

\subsection{Inclusion criteria}

married women who are involved in different women's groups and living in the community of Kawasoti -13, Nawalparasi, willing to participate in the study and available during the data collection period.

\subsection{Ethical committee approval}

Ethical clearance was obtained from Chitwan Medical College-IRC Bharatpur, Chitwan, Nepal. Data collection permission was obtained from the Kawasoti municipality office, Nawalparasi. The purpose of the study was explained to the participants. Verbal consent was taken from all respondents before the data collection. Privacy was maintained by using code numbers for each respondent. Confidentiality was maintained by not disclosing the information to others and assured that the information will be used for study purposes only. Respondents were allowed to leave anytime if they wish.

\subsection{Data management and statistical analysis}

The collected data was checked, reviewed, and organized for accuracy, completeness, and consistency. All collected data were analyzed by using a statistical package for social sciences (SPSS) version 20.0. Descriptive statistics were used to calculate (frequency, percentage, mean/median, and standard deviation) for socio-demographic variables and inferential statistics (chi-square) was used to find out the level of awareness regarding domestic violence and selected variables.

\section{Results}

Out of 80 respondents, the majority $36.3 \%$ were from the age group of $30-39$ years, only $13.8 \%$ were from the age group $\geq 50$ years. The mean age of the respondents was 37.64 years with an 8.97 standard deviation.

Table 1. Socio-demographic Characteristics $(n=80)$

\begin{tabular}{|cll|}
\hline Variables & Frequency & Percentage (\%) \\
\hline Age group (in years) & & \\
$20-29$ & 17 & 21.1 \\
$30-39$ & 29 & 36.3 \\
\hline
\end{tabular}




\begin{tabular}{|c|c|c|}
\hline $40-49$ & 23 & 28.8 \\
\hline$\geq 50$ & 11 & 13.8 \\
\hline \multicolumn{3}{|c|}{ Mean age $\pm S D=37.64 \pm 8.973$, Minimum $=23$ years, Maximum $=59$ years } \\
\hline \multicolumn{3}{|l|}{ Ethnicity } \\
\hline Brahmin/Chhetri & 25 & 31.3 \\
\hline Janajati & 50 & 62.5 \\
\hline Dalit & 5 & 6.2 \\
\hline \multicolumn{3}{|l|}{ Religion } \\
\hline Hindu & 78 & 97.5 \\
\hline Christian & 2 & 2.5 \\
\hline \multicolumn{3}{|l|}{ Education status } \\
\hline Literate & 61 & 76.3 \\
\hline Illiterate & 19 & 23.7 \\
\hline \multicolumn{3}{|c|}{ Education qualification(n=61) } \\
\hline Can read and write only & 13 & 21.3 \\
\hline Basic education & 19 & 31.18 \\
\hline Secondary education & 17 & 27.86 \\
\hline Higher education & 7 & 11.47 \\
\hline Bachelor and above & 5 & 8.19 \\
\hline \multicolumn{3}{|l|}{ Occupation } \\
\hline Agriculture & 47 & 58.8 \\
\hline Business & 11 & 13.8 \\
\hline House maker & 8 & 10.0 \\
\hline Daily wage & 5 & 6.3 \\
\hline Service & 9 & 11.1 \\
\hline
\end{tabular}

Table 1 shows that $62.5 \%$ were Janajati and $6.3 \%$ were Dalit. Concerning religion, $97.5 \%$ of respondents followed Hinduism and $2.5 \%$ followed Christianity. Regarding education status, $76.3 \%$ were literate and $23.8 \%$ were illiterate. Among the literate, $31.14 \%$ were basic level and $8.19 \%$ were bachelor and above level. Concerning occupation, most of the respondents $58.8 \%$ were involved in agriculture and only $6.3 \%$ were involved in daily wage. 
Asian Journal of Basic Science \& Research Volume 4, Issue 1, Pages 45-59, January-March 2022

Table 2. Type of Family, marriage, Duration and Involvement of Domestic Violence Awareness Program ( $\mathrm{n}=80$ )

\begin{tabular}{|c|c|c|}
\hline Variables & Frequency & Percentage $(\%)$ \\
\hline \multicolumn{3}{|l|}{ Type of family } \\
\hline Nuclear family & 48 & 60.0 \\
\hline Joint family & 32 & 40.0 \\
\hline \multicolumn{3}{|l|}{ Type of marriage } \\
\hline Love marriage & 25 & 31.5 \\
\hline Arrange marriage & 55 & 68.5 \\
\hline \multicolumn{3}{|l|}{ Marriage duration } \\
\hline $2-5$ years & 7 & 8.8 \\
\hline $6-9$ years & 9 & 11.2 \\
\hline$\geq 10$ years & 64 & 80.0 \\
\hline \multicolumn{3}{|c|}{ Participation in the awareness programme } \\
\hline Yes & 25 & 31.3 \\
\hline No & 55 & 68.7 \\
\hline \multicolumn{3}{|c|}{ Sources of information $* *$} \\
\hline Family member & 50 & 62.5 \\
\hline Friends & 72 & 90.0 \\
\hline Television & 44 & 55.0 \\
\hline Radio & 16 & 20.0 \\
\hline Newspaper & 7 & 8.8 \\
\hline \multicolumn{3}{|c|}{ Previous exposure to domestic violence } \\
\hline Yes & 38 & 47.5 \\
\hline No & 42 & 52.5 \\
\hline
\end{tabular}

** multiple responses

Table 2 show that $66.0 \%$ of the respondent was belongs to a nuclear family and $40.0 \%$ belong to a joint family. Regarding the type of marriage, $68.3 \%$ have arranged marriage and $31.3 \%$ have a love marriage. Concerning marriage duration, $80.0 \%$ have $\geq 10$ years' duration and only $8.8 \%$ have $2-5$ years duration. Regarding participation in the awareness program, only $31.3 \%$ have participated. Regarding sources of information, $62.5 \%$ received 
information from a family member and $8.8 \%$ from the newspaper. Regarding the experience of domestic violence, $47.5 \%$ have experienced it.

Table 3. Meaning, Most Common Sufferer and Causes of Domestic Violence $(n=80)$

\begin{tabular}{|c|c|c|}
\hline Variables & Frequency & $\begin{array}{c}\text { Percentage } \\
(\%)\end{array}$ \\
\hline \multicolumn{3}{|l|}{ Meaning of domestic violence } \\
\hline Violent by community people in the community setting & 4 & 5.0 \\
\hline $\begin{array}{l}\text { Violent by an intimate partner and family members with } \\
\text { in-home* }\end{array}$ & 76 & 95.0 \\
\hline \multicolumn{3}{|l|}{ A most common sufferer of domestic violence } \\
\hline Married women* & 79 & 98.7 \\
\hline Unmarried women & 1 & 1.3 \\
\hline \multicolumn{3}{|l|}{ The main perpetrator of domestic violence } \\
\hline Neighbor & 2 & 2.5 \\
\hline Husband/father and mother in law* & 78 & 97.5 \\
\hline \multicolumn{3}{|l|}{ Causes of domestic violence** } \\
\hline Unemployment* & 53 & 66.3 \\
\hline Illiteracy* & 59 & 73.0 \\
\hline Substance abuse* & 71 & 88.8 \\
\hline Childlessness/son preference* & 49 & 61.3 \\
\hline Dowry * & 45 & 56.3 \\
\hline Women's education & 1 & 1.3 \\
\hline Self-dependent women & 3 & 3.8 \\
\hline
\end{tabular}

* correct answer $\quad * *$ Multiple responses

Table 3 shows that $95.0 \%$ of respondents had answered that domestic violence is violent by an intimate partner and family members within the home. Regarding the most common sufferer of domestic violence, $98.8 \%$ of respondents answered married women.

Likewise, $97.5 \%$ of respondents answered that husband/ father and mother-in-law are the main perpetrators. About the causes of domestic violence, $88.8 \%$ said substance abuse and $56.3 \%$ said dowry. 
Asian Journal of Basic Science \& Research Volume 4, Issue 1, Pages 45-59, January-March 2022

Table 4. Awareness regarding Types of Domestic Violence $(n=80)$

\begin{tabular}{|c|c|c|}
\hline Variables & Frequency & Percentage $(\%)$ \\
\hline \multicolumn{3}{|l|}{ Different forms of physical violence $* *$} \\
\hline Slapping* & 79 & 98.8 \\
\hline Kicking/dragging* & 75 & 93.8 \\
\hline Pushing* & 46 & 57.5 \\
\hline Pulling hair* & 74 & 92.5 \\
\hline Throwing object* & 46 & 57.5 \\
\hline Insulting & 4 & 5.0 \\
\hline \multicolumn{3}{|l|}{ Different forms of psychological violence $* *$} \\
\hline Blaming* & 80 & 100.0 \\
\hline Threat to remarry/divorce* & 58 & 72.5 \\
\hline Decision without consulting* & 18 & 22.5 \\
\hline Insulting* & 56 & 70.0 \\
\hline Humiliation* & 67 & 83.8 \\
\hline Stopping to job & 8 & 10.0 \\
\hline Controlling over financial resources & 5 & 6.3 \\
\hline \multicolumn{3}{|l|}{ Different forms of sexual violence ** } \\
\hline Uncomfortable touch* & 65 & 81.3 \\
\hline Sexual harassment* & 34 & 42.5 \\
\hline Marital rape* & 52 & 65.0 \\
\hline $\begin{array}{l}\text { Force for the sexual relationship without women's } \\
\text { will* }\end{array}$ & 76 & 95.0 \\
\hline Force prostitution* & 48 & 60.0 \\
\hline Tried to choke her & 2 & 2.5 \\
\hline \multicolumn{3}{|l|}{ Different forms of economic violence** } \\
\hline Controlling over financial resources* & 21 & 26.3 \\
\hline Husband get takes their income by force* & 76 & 95.0 \\
\hline
\end{tabular}




\begin{tabular}{|lcc|}
\hline Prevent economic independence* & 16 & 20.0 \\
\hline Control spending obsessively* & 44 & 55.0 \\
\hline Using economic resources without her consent* & 46 & 57.5 \\
\hline Threatening & 6 & 7.5 \\
\hline
\end{tabular}

* correct answer ** multiple responses

Table 4 shows that, out of 8 respondents, $98.8 \%$ respondents answered slapping and 57.5\% answered pushing and throwing objects were a common form of physical violence. Most all answered blaming and $22.55 \%$ answered decisions without consulting were a form of psychological violence. Nearly cent percentage $95.0 \%$ said force for sexual relationships without women's will and $42.5 \%$ answered sexual harassment was a different form of sexual violence. Regarding different forms of economic violence, $95.0 \%$ of respondents said husband get takes their income by force and $20 \%$ said prevent economic dependence.

Table 5. Health Problems from Domestic Violence $(n=80)$

\begin{tabular}{|c|c|c|}
\hline Variables & Frequency & Percentage $(\%)$ \\
\hline \multicolumn{3}{|l|}{ Immediate physical health problems ** } \\
\hline Injuries* & 78 & 97.5 \\
\hline Bleeding* & 71 & 88.8 \\
\hline Bruises* & 68 & 85.0 \\
\hline Fracture* & 56 & 70.0 \\
\hline Swollen body parts* & 44 & 55.0 \\
\hline \multicolumn{3}{|l|}{ Long term physical health problems** } \\
\hline Body ache * & 72 & 90.0 \\
\hline Permanent disability* & 65 & 81.0 \\
\hline Unwanted pregnancy* & 17 & 21.3 \\
\hline Pelvic inflammatory disease* & 24 & 30.0 \\
\hline HIV/aids* & 9 & 11.3 \\
\hline \multicolumn{3}{|l|}{ Psychological health problems** } \\
\hline Low self-esteem* & 60 & 75.0 \\
\hline Depression* & 75 & 93.8 \\
\hline Sleeping problem* & 76 & 95.0 \\
\hline Substance abuse* & 38 & 47.5 \\
\hline
\end{tabular}




\begin{tabular}{|ccc|}
\hline Eating disorder* & 65 & 81.3 \\
Mental retardation & 12 & 15.0 \\
Health problems in pregnant women ** & & \\
Miscarriage* & 76 & 95.0 \\
Antepartum hemorrhage* & 78 & 97.5 \\
Premature birth* & 47 & 58.8 \\
Low birth weight* & 18 & 22.5 \\
Still birth* & 57 & 71.3 \\
\hline correct answer ** multiple response & & \\
\hline
\end{tabular}

Table 5 shows that, out of 80 respondents, about $97.5 \%$ answered injuries and $55.0 \%$ answered swollen body parts were immediate physical health problems. About $90.0 \%$ of respondents answered body ache and only $11.3 \%$ answered HIV/Aids as long term physical health problems. About $95.0 \%$ answered sleeping problems and $47.5 \%$ answered substance abuse as a psychological health problem. All most all $97.5 \%$ of respondents answered antepartum haemorrhage and $22.5 \%$ answered low birth weight as a health problem in pregnant women.

Table 6. Preventive Measures and Laws of Domestic Violence $(n=80)$

\begin{tabular}{|lll|}
\hline Variables & Frequency & Percentage (\%) \\
\hline Preventive measures of domestic violence** & 44 & 55.0 \\
\hline Employment opportunity* & 80 & 100.0 \\
Community-based awareness program* & 77 & 96.3 \\
\hline Proper implementation of domestic violence legal & & \\
act* & 63 & 78.8 \\
Involve media in awareness program* & 2 & 2.5 \\
\hline Stopping women to report the case & & \\
\hline Is there a law regarding domestic violence & 78 & 97.5 \\
Yes* & 2 & 2.5 \\
No & & \\
\hline Where to report In case of domestic violence & 55 & 68.7 \\
Police office* & 1 & 1.3 \\
Supreme court & 24 & 30.0 \\
Neighbor & 5 & \\
\hline
\end{tabular}




\begin{tabular}{|c|c|c|}
\hline \multicolumn{3}{|l|}{ Within how many days complaint shall be filled } \\
\hline 30 days & 55 & 68.8 \\
\hline 60 days & 22 & 27.2 \\
\hline 90 days* & 2 & 2.5 \\
\hline 120 days & 1 & 1.5 \\
\hline \multicolumn{3}{|l|}{$\begin{array}{l}\text { Is the offender responsible for all types of damage \& } \\
\text { injuries }\end{array}$} \\
\hline Yes* & 64 & 80.0 \\
\hline No & 16 & 20.0 \\
\hline \multicolumn{3}{|l|}{ Maximum punishment of the offender } \\
\hline 1-month imprisonment or $2500-15000$ or both & 20 & 25.0 \\
\hline 3 months imprisonment or 2000-10000 or both & 23 & 28.8 \\
\hline 6 months imprisonment or $3000-25000$ or both* & 16 & 20.0 \\
\hline 12 months imprisonment or $5000-30000$ or both & 21 & 26.2 \\
\hline
\end{tabular}

* correct answer ** multiple responses

Table 6 shows that out of 80 respondents, all most answered community-based awareness programs and 55.0\% answered employment opportunities are the preventive measures of domestic violence. Similarly, $97.5 \%$ answered there is a law regarding domestic violence in Nepal. Likewise, $68.8 \%$ of respondents answered that cases of domestic violence should be reported in the police station.

Only 2.55 respondents answered that complaints of domestic violence shall be filled within 90 days. About $80 \%$ of respondents answered offender is responsible for all types of damage and injuries. Similarly, 20\% of respondents answered that the maximum punishment of the offender is 6 months imprisonment or 3000-25000 or both.

Table 7. Immediate and Long Term Management of Domestic Violence $(\mathrm{n}=80)$

\begin{tabular}{|lll|}
\hline Variables & Frequency & Percentage $(\%)$ \\
\hline Immediate management of domestic violence*** & & \\
Seek medical treatment* & 73 & 91.3 \\
Report case in police station* & 79 & 98.8 \\
Separate her from offender* & 41 & 51.3 \\
Emotional support* & 66 & 82.5 \\
Support to perpetrator & 2 & 2.5 \\
\hline
\end{tabular}




\begin{tabular}{|lll|}
\hline Social isolation & 2 & 2.5 \\
\hline Long term management of domestic violence** & & \\
\hline Counselling to survivor and perpetrator* & 69 & 86.3 \\
\hline Legal treatment* & 76 & 95.0 \\
Employment opportunity* & 61 & 76.3 \\
Women education* & 58 & 72.5 \\
Social support* & 63 & 78.8 \\
Social isolation & 2 & 2.5 \\
\hline Punishment to women & 1 & 1.3 \\
\hline
\end{tabular}

* correct answer $\quad * *$ multiple response

Table 7 shows that out of 80 respondents, most of the respondents $98.8 \%$ answered reported cases in the police station and $51.3 \%$ answered separate her from the offender are the immediate management of domestic violence. About $95.0 \%$ answered legal treatment and only $72.5 \%$ answered women education is the long term management of domestic violence.

Table 8. Respondents’ Level of Awareness regarding Domestic Violence $(n=80)$

\begin{tabular}{|ccc|}
\hline Level of awareness & Number & Percentage $(\%)$ \\
\hline Adequate awareness $(\geq \mathbf{1 4 . 2 3})$ & 46 & 57.5 \\
Inadequate awareness $(<\mathbf{1 4 . 2 3})$ & 34 & 42.5 \\
Total & 80 & 100.0 \\
\hline
\end{tabular}

Mean value-14.23, min-9, max-18.80

Table 8 shows that out of 80 respondents more than half percent $57.5 \%$ had adequate awareness and $42.5 \%$ of respondents had inadequate awareness levels regarding domestic violence.

Table 9. Association between Level of Awareness of Domestic Violence and Selected Demographic Variables

\begin{tabular}{|c|c|c|c|}
\hline \multirow[t]{2}{*}{ Variables } & \multicolumn{2}{|c|}{ Level of awareness } & \multirow[b]{2}{*}{ P-value } \\
\hline & $\begin{array}{l}\text { Adequate } \\
\text { No. }(\%)\end{array}$ & $\begin{array}{l}\text { Inadequate } \\
\text { No. }(\%)\end{array}$ & \\
\hline \multicolumn{4}{|c|}{ Age group (in years) } \\
\hline 20-39 & $31(67.4)$ & $15(32.6)$ & 0.037 \\
\hline$\geq 40$ & $15(44.1)$ & $19(55.9)$ & \\
\hline
\end{tabular}




\begin{tabular}{|c|c|c|c|}
\hline \multicolumn{4}{|l|}{ Ethnicity } \\
\hline Brahmin/Chhetri & $16(64)$ & $9(36)$ & 0.428 \\
\hline Others ( Janajati \& Dalit) & $30(54.5)$ & $25(45.5)$ & \\
\hline \multicolumn{4}{|l|}{ Religion } \\
\hline Hindu & $45(57.7)$ & $33(42.3)$ & $1.000 * *$ \\
\hline Christian & $1(50.0)$ & $1(50.0)$ & \\
\hline \multicolumn{4}{|l|}{ Education status } \\
\hline Literate & $45(57.7)$ & $16(26.3)$ & $<0.001$ \\
\hline Illiterate & $1(5.3)$ & $18(19.7)$ & \\
\hline \multicolumn{4}{|l|}{ Education qualification } \\
\hline Higher secondary and above & $10(83.3)$ & $2(16.7)$ & $0.569 *$ \\
\hline Below higher secondary & $34(70.0)$ & $15(30.0)$ & \\
\hline \multicolumn{4}{|l|}{ Occupation } \\
\hline Service (service+ business) & $19(95.0)$ & $1(5.0)$ & $<0.001$ \\
\hline $\begin{array}{l}\text { Other (agriculture+ house maker+ daily } \\
\text { wage) }\end{array}$ & $27(45.0)$ & $33(55.0)$ & \\
\hline \multicolumn{4}{|l|}{ Type of family } \\
\hline Nuclear family & $29(60.4)$ & 19(39.6) & 0.518 \\
\hline Joint family & $17(53.1)$ & $15(46.9)$ & \\
\hline
\end{tabular}

*Continuity correction $\quad$ ** fisher's exact test $\quad$ Significance level at $<0.05$

Table 9 shows the association between respondents level of awareness regarding domestic violence and selected variables.

The level of awareness regarding domestic violence was significant with the age group of respondents $(\mathrm{p}=0.037)$, with education status $(\mathrm{p}=0.000)$, with the occupation of respondents $(\mathrm{p}=0.000)$ and with income adequate to family $(\mathrm{p}=0.001)$.

The level of awareness regarding domestic violence was not significant with ethnicity $(\mathrm{p}=0.428)$, religion $(\mathrm{p}=1.000)$, education qualification $(\mathrm{p}=0.569)$ and type of family $(\mathrm{p}=0.518)$. 
Table 10. Association between Level of Awareness of Domestic Violence and Selected Demographic Variables

\begin{tabular}{|c|c|c|c|}
\hline \multirow[t]{2}{*}{ Variables } & \multicolumn{2}{|c|}{ Level of awareness } & \multirow[t]{2}{*}{ p-value } \\
\hline & $\begin{array}{l}\text { Adequate } \\
\text { No (\%) }\end{array}$ & $\begin{array}{l}\text { Inadequate } \\
\text { No }(\%)\end{array}$ & \\
\hline \multicolumn{4}{|l|}{ Type of marriage } \\
\hline Love marriage & $20(80.0)$ & $5(20.0)$ & \multirow[t]{2}{*}{0.006} \\
\hline Arrange marriage & $26(47.3)$ & $29(52.7)$ & \\
\hline \multicolumn{4}{|l|}{ Marriage duration } \\
\hline 2-9 years & $12(75.0)$ & $4(25.0)$ & $0.113^{*}$ \\
\hline$\geq 10$ years & $34(53.1)$ & $30(46.9)$ & \\
\hline \multicolumn{4}{|c|}{ Participation in the awareness program } \\
\hline Yes & 23(92.0) & $2(8.0)$ & \multirow[t]{2}{*}{$<0.001 *$} \\
\hline No & $23(41.8)$ & $32(58.2)$ & \\
\hline \multicolumn{4}{|l|}{ Previous experience } \\
\hline Yes & $20(52.6)$ & $18(47.4)$ & \multirow[t]{2}{*}{0.402} \\
\hline No & $26(61.9)$ & $16(38.1)$ & \\
\hline
\end{tabular}

Significance level at $<0.05 \quad *$ continuity correction

Table 10 shows that the level of awareness regarding domestic violence was significant with the type of marriage of respondents $(\mathrm{p}=0.006)$ and participation in awareness programs $(\mathrm{p}=0.000)$. The level of awareness on domestic violence was not significant with experience of domestic violence $(\mathrm{p}=0.402)$.

\section{Discussions}

In our study, the prevalence of domestic violence was experienced by $47.5 \%$ of women. Whereas the study findings were in contrast to the finding of Nadda et al (2018). Which revealed that the prevalence rate of domestic violence was experienced by $28.9 \%$ of women [11].

Regarding the main perpetrators of domestic violence, $97.5 \%$ said husband/father in law and mother in law are the main perpetrator of domestic violence. This finding is similar to the study conducted by Paneru, (2014) which showed $89.7 \%$ of the respondents answered husbands and in-laws are the main perpetrators [15].

Regarding causes of domestic violence, unemployment, illiteracy, substance abuse, son preference and dowry were the common causes. Among them, $88.8 \%$ said substance abuse by the husband was the most common cause of domestic violence. This study was similar to the study conducted by Giri et al (2017) which shows that the most common cause of domestic violence was substance abuse [16]. The majority of respondents were aware of 
physical, psychological and reproductive health problems which are supported by a study conducted by Paneru (2014) which reveal that $74.3 \%$ were aware of physical health problem, $75.6 \%$ were aware of mental health problem and only $17.8 \%$ were aware of reproductive health problem [15].

More than half (52.6\%) of the respondents had awareness regarding domestic violence after experiencing domestic violence. This finding was inconsistent with the study conducted by Alan, Yilmaz, Filiz, and Arioz (2016) which shows that $40 \%$ were found to know about the legal acts after experiencing domestic violence [17].

The level of awareness regarding domestic violence was adequate in $57.5 \%$. The finding of the study was inconsistent with the study conducted by Paneru (2014) which revealed that $78.1 \%$ had adequate awareness regarding domestic violence [15].

\section{Conclusion}

The conclusions are based on the discussion and findings of the study, more than half have an adequate level of awareness regarding domestic violence. Awareness of domestic violence is good regarding the meaning of domestic violence, most common sufferer of domestic violence, main perpetrator of domestic violence, and inadequate level awareness regarding legal act in Nepal. The level of awareness regarding domestic violence can be upgraded by conducting public awareness training programs regarding domestic violence among women in the community.

\section{Limitations of the study}

The study was conducted only in Kawasoti municipality-13, Nawalparasi. The sample size was 80 only.

\section{Recommendation}

A similar type of study can be conducted in different settings on a large scale for the generalization of findings. The educational intentional study can be conducted emphasizing the lacking area to increase the awareness regarding domestic violence among women in the community.

\section{Acknowledgments}

The authors would like to thank associate professor Govinda Prasad Dhungana for Statistical expert proving us. The authors also acknowledge all the participants without whom this study would not have been possible.

\footnotetext{
Declarations

Source of Funding

This research did not receive any grant from funding agencies in the public, commercial, or not-for-profit sectors. Competing Interests Statement

The authors declare no competing financial, professional and personal interests. 


\section{References}

[1] Cao YP, Zhang YL, Chang DF, Yang SC, Wang GQ. Correlations between self-reported symptoms and psychosocial factors of perpetrators with domestic violence in China: a population-based sample. Chinese Medical Journal. 2011 Feb 1; 124(4): 546-50.

[2] World Health Organization. Global and regional estimates of violence against women: prevalence and health effects of intimate partner violence and non-partner sexual violence. World Health Organization; 2013.

[3] Kambli TD, Kazi YK, Chavan YB, Velhal GD, Aras RY. Study to assess determinants of domestic violence among women in urban slum of Mumbai. Age. 2013; 18(25): 26-35.

[4] Sapkota D, Bhattarai S, Baral D, Pokharel PK. Domestic violence and its associated factors among married women of a village development committee of rural Nepal. BMC research notes. 2016 Dec; 9(1): 1-9.

[5] Biradar S.R. \& Chandrika K.B. Awareness regarding domestic violence in Muslim women. Best International Journal of Humanity, Arts, Medicine and Science. 2016; 4(5), 23-30.

[6] Guru P. Legal Awareness Hubris for Women to Combat Violence. Open Journal of Social Sciences. 2015; 3(09): 223.

[7] Informal Sector Service Center. Violence against Women/Girls: An Assessment of the Situation in Nepal. 2013. [8] Informal Sector Service Center. Violence against Women/Girls: An Assessment of the Situation in Nepal. 2014. [9] Khatri R.B. \& Pandey B. K. Causes of violence against women: a qualitative study at Bardiya district. Health Prospect., 2013; 12(1): 10-14.

[10] Salish K., Ain, O. Violence against Women - Domestic Violence, Jan-June 2020.

[11] Nadda A., Malik J.S., Rohilla R., Chahal S., Chayal V., Arora V. Study of domestic violence among currently married females of Haryana, India. Indian Journal of Psychological Medicine. 2018 Nov; 40(6): 534-539.

[12] Chhabra S. Effects of societal/domestic violence on health of women. J Women's H. Rep. Med. 2018; 2(1): 6. [13] Nesan S.C., Maiya G.R., Kundapur R. Domestic violence patterns and its consequences among married women in rural Mangalore. Indian Journal of Community Health. 2018: 1; 30(2).

[14] Sifat RI. Impact of the COVID-19 pandemic on domestic violence in Bangladesh. Asian Journal of Psychiatry. 2020 Oct; 53: 102393 Retrieved from: http://www.nepjol.info/index.php/HPROSPECT/article/view/8721.

[15] Paneru D.P. Awareness on Domestic Violence against Women and Related Health Outcomes in a Hill District of Nepal. Indian Journal of Applied Research. 2014: 4(8).

[16] Giri S.S., Singh J.K., Giri R., Jha L.K., Yadav S.K. Study on Domestic Violence against women in Nepalese village of Terai Region. Janaki Medical College Journal of Medical Science. 2016; 4(1): 46-52.

[17] Alan H., Yilmaz S.D., Filiz E., Arioz A. Domestic violence awareness and prevention among married women in central Anatolia. Journal of Family Violence. 2016 Aug; 31(6): 711-9. 